\title{
Pelaksanaan Pendidikan Literasi Finansial pada Siswa Sekolah Dasar
}

\author{
Viving Laila ${ }^{1}$, Syamsul Hadi ${ }^{2}$, Subanji ${ }^{3}$ \\ ${ }^{1}$ Pendidikan Dasar-Universitas Negeri Malang \\ ${ }^{2}$ Teknik Mesin-Universitas Negeri Malang \\ ${ }^{3}$ Pendidikan Matematika-Universitas Negeri Malang
}

\begin{tabular}{l}
\hline \hline INFO ARTIKEL \\
\hline Riwayat Artikel: \\
Diterima: 15-05-2019 \\
Disetujui: $14-11-2019$ \\
\hline
\end{tabular}

\section{Kata kunci:}

financial literacy education; elementary school student; pendidikan literasi finansial; siswa sekolah dasar

\begin{abstract}
ABSTRAK
Abstract: This study discusses how to implement financial literacy education in elementary school students. Financial literacy education is a person's activity in applying, understanding and managing information to make financial decisions. Financial literacy education can be taught early to provide knowledge and skills in improving financial well-being. This study uses a descriptive qualitative approach to describe the activities of teachers and students in the implementation of financial literacy education in elementary schools. This study shows that the implementation of financial literacy education can provide positive attitudes for students to participate in production activities and motivate students to save. Teachers can teach financial literacy education in accordance with the basic competencies that already exist in subjects such as mathematics and social studies. Teachers can teach the material the role of the economy in an effort to improve the lives of the people by introducing the type of business and doing activities to make a work and sell it.

Abstrak: Penelitian ini membahas tentang bagaimana melaksanakan pendidikan literasi finansial pada siswa sekolah dasar. Pendidikan literasi finansial merupakan aktivitas seseorang dalam mengaplikasikan, memahami, dan mengelola informasi untuk membuat suatu keputusan finansialnya. Pendidikan literasi finansial dapat diajarkan sejak dini untuk memberikan pengetahuan dan keterampilan dalam meningkatkan kesejahteraan finansialnya. Penelitian ini menggunakan pendekatan kualitatif jenis deskriptif, untuk mendeskripsikan aktivitas guru dan siswa dalam pelaksanaan pendidikan literasi finansial di sekolah dasar. Penelitian ini menunjukkan bahwa pelaksanaan pendidikan literasi finansial dapat memberikan sikap positif siswa untuk berpartisipasi dalam kegiatan produksi dan memotivasi siswa untuk menabung. Guru dapat mengajarkan pendidikan literasi finansial sesuai dengan kompetensi dasar yang sudah ada pada mata pelajaran, seperti Matematika dan IPS. Guru dapat mengajarkan materi peran ekonomi dalam upaya menyejahterakan kehidupan masyarakat dengan mengenalkan jenis usaha serta melakukan kegiatan membuat sebuah karya dan menjualnya.
\end{abstract}

\author{
Alamat Korespondensi: \\ Viving Laila \\ Pendidikan Dasar \\ Universitas Negeri Malang \\ Jalan Semarang 5 Malang \\ E-mail: vivinglaila@gmail.com
}

Indonesia termasuk salah satu negara berkembang yang tingkat pengetahuan literasi finansialnya tergolong rendah. Hal ini sesuai dengan hasil survei oleh OJK pada tahun 2017 mencapai 29,7\%. Kondisi ini membuktikan rendahnya pemahaman dan kedekatan masyarakat dalam akses finansial. Kondisi ini menyebabkan pemerintah untuk melakukan upaya dengan mengajarkan pendidikan literasi finansial. Pendidikan literasi finansial termasuk salah satu literasi dasar dalam keterampilan abad 21 yang digunakan untuk menghadapi kehidupan dunia global agar mampu bersaing dan bersanding dengan bangsa lain dalam menciptakan kesejahteraan. Kesejahteraan akan finansial dapat meningkat, jika ada peranan sekolah dalam memberikan pengetahuan dan keterampilan pada siswa sejak sekolah dasar. Hal ini juga dijelaskan oleh Permata (2017) tentang pentingnya materi literasi finansial yang diberikan pada anak usia dini karena dalam kehidupan sehari-hari sebagian aktivitas yang dilakukan seseorang hampir tidak lepas dari kegiatan ekonomi.

Peran pendidikan literasi finansial di sekolah dasar tidak hanya sekedar mengenalkan uang, namun juga mempelajari tentang pengelolaan uang, belajar bertransaksi, dan dapat memiliki jiwa kewirausahaan. Hal ini juga dijelaskan dalam penelitian Johnson (2006) bahwa peran pendidikan literasi finansial bagi sekolah dasar sangatlah penting agar memiliki kemampuan untuk memahami, menilai dan bertindak dalam kesejahteraan finansialnya. Menurut Vitt dkk (2000) pendidikan 
literasi finansial adalah proses seseorang untuk memperoleh kemampuan dalam mengaplikasikan, memahami serta mengelola informasi untuk membuat suatu keputusan finansialnya. Hal ini juga didukung dengan penelitian oleh Batty dkk (2015) tentang pengaruh pendidikan finansial di sekolah dasar dapat membantu siswa untuk memiliki sifat positif dalam mengelola keuangan dan lebih cenderung menabung. Berdasarkan penjelasan di atas dapat disimpulkan bahwa pendidikan literasi finansial merupakan proses yang dilakukan seseorang dalam memperoleh pengetahuan dan keterampilan untuk memahami, mengaplikasikan, dan membuat keputusan guna meningkatkan kesejahteraan finansialnya. Pendidikan literasi finansial dapat meningkatkan pemahaman siswa dalam memahami konsep, menambah informasi, mengembangkan keterampilan guna membuat suatu keputusan dalam meningkatkan kesejahteraan finansialnya (Delgadillo, 2014).

Pendidikan literasi finansial memiliki empat konsep yang dapat membantu guru mengoordinasikan materi dengan kehidupan sehari-hari siswa. Menurut Jackson (2013) terdapat empat konsep yang bisa diajarkan dalam pendidikan literasi finansial siswa sekolah dasar, yaitu memperoleh, menyimpan, membelanjakan, dan mendonasikan. Konsep pertama, yaitu memperoleh mengajarkan bahwa uang didapat karena kita bekerja atau berwirausaha. Guru dapat memberikan berbagai macam keterampilan kepada siswa dan melatih siswa untuk melakukan kegiatan menjual produk yang mereka buat disekitar sekolah. Konsep kedua, yaitu menyimpan ini memberikan pengetahuan dan motivasi kepada siswa agar mampu menyimpan uang yang mereka miliki. Menurut Owen (2003) kecerdasan finansial siswa dapat terjadi jika siswa dapat memiliki keterampilan dalam mengelola keuangan dengan baik dan selalu dilatih untuk menabung. Konsep ketiga, membelajankan memiliki manfaat agar siswa dapat membedakan antara kebutuhan dengan keinginan. Hal yang dapat dilakukan oleh guru yaitu dengan membuat rencana pengeluaran dan juga membuat jurnal atau cerita tentang pengalaman siswa dalam membeli sesuatu yang dibutuhkan. Konsep yang terakhir yaitu mendonasikan, konsep ini mengajarkan kepada siswa untuk selalu berbagi dengan orang lain. Konsep dalam pendidikan literasi finansial ini harus diajarkan sesuai dengan karakteristik usia siswa sekolah dasar. Hal ini didukung oleh pendapat Otto (2006) bahwa usia anak antara umur 6 - 9 tahun siswa sudah mengenal dan mengalokasikan uang yang dimiliki untuk kegiatan menabung dan pada usia 10-12 tahun siswa mampu membuat suatu rencana mengatur keuangan secara mandiri untuk melakukan transaksi jual beli.

Pendidikan literasi finansial di sekolah dasar dapat diintegrasikan dengan mata pelajaran lain. Hal ini sesuai dengan penjelasan dari Dikdasmen (2017) pelaksanaan pendidikan literasi finansial pada siswa sekolah dasar dapat dilakukan dengan mengintegrasikan mata pelajaran yang sudah ada dan penekanannya pada praktik yang disesuaikan dengan kegiatan literasi finansial. Pendidikan literasi finansial dapat ditemukan di mata pelajaran matematika dan ilmu pengetahuan sosial. Guru harus menguasai konsep dasar literasi finansial dan mengajarkan secara efektif, kreatif, dan praktis agar siswa dapat menguasai, berlatih dan mengaitkan dalam kehidupan sehari-hari dalam mengambil suatu keputusan dalam lingkup finansialnya (Elonge, 2013). Pembelajaran dapat efektif, aktif, dan menyenangkan, jika guru menggunakan metode dan media yang dapat membantu pemahaman siswa dan tercapainya tujuan pembelajaran. Metode pembelajaran memiliki berbagai macam jenis dalam proses pembelajaran, namun tidak semua metode tersebut cocok digunakan dalam kegiatan pembelajaran. Hal ini harus dipahami oleh guru sebelum menggunakan metode pembelajaran yang harus disesuaikan dengan tujuan, kondisi, dan karakteristik siswa. Menurut Roof (2004) pendidik harus menggunakan berbagai macam metode pembelajaran yang disesuaikan dengan usia siswa agar dapat membantu meningkatkan pemahaman siswa terkait konsep finansial.

\section{METODE}

Jenis penelitan ini menggunakan penelitian kualitatif deskriptif. Peneliti bertindak sebagai pengamat nonpartisipan dan kehadiran peneliti diketahui oleh narasumber. Subjek penelitian yang digunakan yaitu siswa kelas V sekolah dasar. Teknik pengumpulan data dalam penelitian ini, meliputi wawancara, observasi, dan dokumentasi. Wawancara dilakukan dengan kepala sekolah, guru, koordinator perpustakaan dan siswa kelas V. Data observasi diperoleh dari kegiatan pelaksanaan literasi finansial selama pembelajaran di kelas dan kegiatan tindak lanjut. Data dokumentasi yang diambil yaitu rencana pelaksanaan pembelajaran, potret kegiatan pendidikan literasi finansial dan sarana penunjang literasi finansial. Penelitian melakukan penelitian di sekolah dasar sampai peneliti memperoleh data jenuh dan menemukan jawaban yang konstan sesuai fokus penelitian. Analisis data yang digunakan dalam penelitian ini yaitu organisasi data, pembacaan data (memoing), mendeskripsikan data menjadi kode, mengklasifikasikan coding ke dalam tema, menafsirkan data, dan menyajikan data (Cresswell, 2018).

\section{HASIL}

Pelaksanaan pendidikan literasi finansial yang dilakukan di kelas ditentukan berdasarkan adanya kebijakan, tahap pembelajaran literasi finansial, sarana literasi finansial dan pelibatan publik. Berikut rangkaian kegiatan pelaksanaan pendidikan literasi finansial yang dapat dilakukan siswa kelas V sekolah dasar dapat dilihat pada tabel 1. 
Tabel 1. Pelaksanaan Pendidikan Literasi Finansial

\begin{tabular}{|c|c|c|}
\hline Pendidikan Literasi Finansial & Aktivitas & $\begin{array}{c}\text { Konsep Literasi } \\
\text { Finansial }\end{array}$ \\
\hline Kebijakan & $\begin{array}{ll}\text { - } & \text { Salah satu bagian dari kegiatan gerakan literasi } \\
\text { sekolah } & \text { Melakukan kegiatan wirausaha } \\
\text { - } & \text { Terdapat workshop tentang pelatihan daur ulang } \\
\text { yang dapat menghasilkan produk. } \\
\text { - } \quad \text { Terdapat kompetensi dasar yang berhubungan } \\
\text { dengan pendidikan literasi finansial }\end{array}$ & $\begin{array}{ll}- & \text { Memperoleh } \\
- & \text { Menyimpan } \\
- & \text { Membelanjakan }\end{array}$ \\
\hline $\begin{array}{l}\text { Tahap pembelajaran (Pembelajaran ilmu pengetahuan } \\
\text { sosial materi peran ekonomi dalam upaya } \\
\text { menyejahterakan kehidupan dilingkungan masyarakat) }\end{array}$ & $\begin{array}{l}\text { - } \quad \text { Siswa dikenalkan dengan berbagai jenis ekonomi } \\
\text { yang ada dilingkungan sekitar } \\
\text { - } \quad \text { Siswa mengunjungi pasar tradisional di sekitar } \\
\text { sekolah } \\
\text { - } \quad \text { Siswa melakukan wawancara dengan pedagang } \\
\text { - } \quad \text { Siswa dilatih untuk membuat wadah pensil } \\
\text { berkarakter dan keterampilan lainnya }\end{array}$ & $\begin{array}{ll}- & \text { Memperoleh } \\
- & \text { Menyimpan } \\
- & \text { Membelanjakan }\end{array}$ \\
\hline Sarana Penunjang & $\begin{array}{l}\text { - } \quad \begin{array}{l}\text { Siswa memperoleh pengetahuan dari buku fiksi } \\
\text { dan non fiksi terkait finansial }\end{array} \\
\text { - } \quad \text { Siswa memperoleh ilmu dari permainan dan video } \\
\text { pembelajaran literasi finansial }\end{array}$ & $\begin{array}{ll}- & \text { Memperoleh } \\
- & \text { Menyimpan } \\
- & \text { Membelanjakan } \\
\text { - } & \text { Mendonasikan }\end{array}$ \\
\hline Pelibatan publik & $\begin{array}{l}\text { - } \quad \text { Membiasakan siswa untuk menabung di salah satu } \\
\text { Bank } \\
\text { - } \quad \text { Menyediakan buku untuk sudut baca }\end{array}$ & Menyimpan \\
\hline Tindak lanjut & 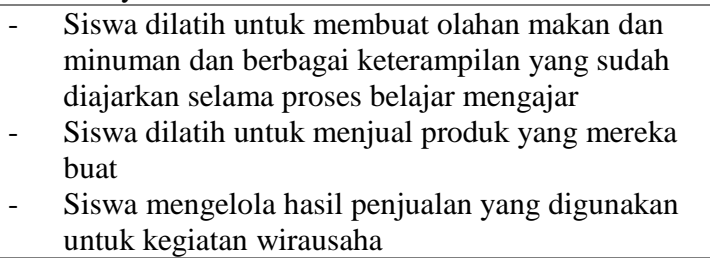 & $\begin{array}{ll}- & \text { Memperoleh } \\
- & \text { Menyimpan } \\
- & \text { Membelanjakan }\end{array}$ \\
\hline
\end{tabular}

Berdasarkan tabel 1 di atas dapat dijelaskan bahwa pendidikan literasi finansial di sekolah dasar dilaksanakan sejak tahun 2017, termasuk salah satu bagian dari gerakan literasi finansial. Kebijakan dari Walikota Surabaya dalam memberikan pendidikan literasi finansial sudah dilaksanakan sejak tahun 2017. Hal ini dapat dilihat dari adanya brosur tentang program yang harus dilakukan sekolah untuk melakukan tantangan dalam wirausaha lingkungan hidup dan kegiatan workshop tentang pelatihan membuat keterampilan di dalam kelas. Pendidikan literasi finansial basis kelas juga dilaksanakan sesuai dengan kompetensi dasar dan tema yang sudah ditetapkan oleh pemerintah. Kompetensi dasar ini merupakan sejumlah kemampuan minimal yang harus dimiliki oleh siswa dalam menguasai mata pelajaran tertentu. Kompetensi dasar yang ada dikelas rendah berbeda dengan yang dikelas tinggi. Kompetensi dasar di kelas rendah (kelas II dan III yang berhubungan dengan pendidikan literasi finansial terdapat pada pembelajaran Matematika Kompetensi dasar pada kelas tinggi (kelas IV dan V) yaitu terdapat pada pembelajaran IPS.

Pendidikan literasi finansial dalam tahap pembelajaran sudah dilaksanakan dengan baik. Hal ini dapat dilihat dari proses pembelajaran selama kegiatan di kelas. Guru menggunakan berbagai metode dan media pembelajaran untuk membantu pemahaman siswa. Guru mengajarkan pendidikan literasi finansial materi jenis-jenis ekonomi dimasyarakat. Konsep pendidikan literasi finansial yang bersifat abstrak dapat diubah menjadi konkret dengan bantuan suatu media pembelajaran. Media yang dipakai guru dalam mengajarkan pendidikan literasi finansial, yaitu media video. Adanya media ini dapat membantu pemahaman siswa dan menjadikan pembelajaran aktif dan menyenangkan. Guru menggunakan metode karyawisata dengan melakukan wawancara pedagang di pasar terdekat sekolah. Sekolah juga melakukan tindak lanjut dengan mengadakan kegiatan bazar. Kegiatan bazar ini menjual hasil karya dan siswa secara langsung menjual produk tersebut khususnya kelas V. Para guru bersama siswa menyediakan tempat untuk menjual karyanya di lapangan sekolah. Produk yang mereka jual berbagai macam dari makanan, minuman serta keterampilan topi bulu dan tempat pensil berkarakter.

Pendidikan literasi finansial dapat didukung dengan adanya sarana literasi perpustakaan dan sudut baca kelas. Perpustakaan digunakan sebagai tempat proses belajar mengajar setiap hari Senin-Jumat. Setiap kelas memiliki jadwal yang berbeda-beda untuk datang dan belajar di perpustakaan. Guru memberikan tugas setiap jenjang kelas yang berbeda-beda sesuai dengan topik yang akan diajarkan. Guru juga memberikan pengetahuan dan keterampilan yang berhubungan dengan pendidikan literasi finansial. Perpustakaan juga menyediakan video pembelajaran, buku fiksi dan non fiksi, serta permainan monopoli dalam memberikan pendidikan literasi finansial. Sarana sudut baca kelas juga digunakan sebagai penyediaan bahan bacaan dalam memperoleh ilmu pengetahuan tentang pendidikan literasi finansial yang ada di dalam kelas I. Penyediaan buku di sudut 
baca kelas bekerja sama dengan orangtua siswa. Sekolah juga bekerja sama dengan salah satu Bank untuk memotivasi dan memberikan pelayanan menabung yang aman bagi anak-anak.

\section{PEMBAHASAN}

\section{Pelaksanaan Pendidikan Literasi Finansial Basis Kelas}

Pendidikan literasi finansial termasuk dalam gerakan literasi sekolah, hal ini sesuai dengan kutipan menurut Dikdasmen (2017) yang mengelompokkan kegiatan literasi menjadi enam aspek literasi dasar antara lain literasi bahasa, literasi numerasi, literasi sains, literasi digital, literasi finansial, serta literasi budaya dan kewarganegaraan. Pendidikan literasi finansial basis kelas dilakukan berdasarkan adanya kompetensi dasar yang sudah ada dan dimuat dalam beberapa mata pelajaran. Hal ini sesuai dengan kutipan menurut Dikdasmen (2017) pendidikan literasi finansial pada siswa sekolah dasar dapat dilakukan dengan mengintegrasikan dalam mata pelajaran yang sudah ada dan penekanannya pada praktik yang disesuaikan pada kompetensi dasar. Kompetensi dasar ini digunakan sebagai pedoman guru dalam memberikan pengetahuan dan keterampilan kepada siswa untuk meningkatkan finansial yang akan dimiliki. Fakta di lapangan menunjukkan bahwa kegiatan literasi finansial sudah ada pada tahun 2017. Peneliti memperoleh dokumentasi pada tahun 2017 yaitu adanya workshop yang diadakan di dalam kelas tentang pelatihan daur ulang sampah plastik yang dapat menghasilkan produk dan brosur tantangan yang diadakan oleh walikota Surabaya tentang pelaksanaan wirausaha lingkungan hidup (kegiatan bazar). Kebijakan walikota Surabaya dalam melaksanakan kegiatan bazar untuk mendukung salah satu bagian dari gerakan literasi sekolah, yaitu literasi finansial.

Pelaksanaan pendidikan literasi finansial di kelas disesuaikan dengan kompetensi dasar yang akan diajarkan. Kompetensi dasar ini dimuat dalam setiap mata pelajaran yang sudah ada di jenjang sekolah dasar. Kompetensi dasar yang memuat tentang pendidikan literasi finansial terintegrasi dengan mata pelajaran lain, jadi pendidikan literasi finansial tidak berdiri sendiri dalam mata pelajaran. Menurut Dirjen Dikdasmen (2017b) pelaksanaan pendidikan literasi finansial pada siswa sekolah dasar dapat dilakukan dengan mengintegrasikan pelajaran yang sudah ada dan penekanannya pada praktik yang disesuaikan pada kegiatan literasi finansial. Pendidikan literasi finansial pada siswa sekolah dasar dapat ditemukan dalam mata pembelajaran lain yaitu matematika dan Ilmu Pengetahuan Sosial. Menurut Mosley (2016) pada tingkat sekolah dasar konsep pendidikan literasi finansial dapat ditemukan dalam pembelajaran matematika, bahasa Indonesia dan ilmu pendidikan sosial. Hal ini sesuai dengan fakta lapangan bahwa pendidikan literasi finansial dapat ditemukan dalam kompetensi dasar pada siswa kelas II (rendah) dan kelas V (kelas tinggi). Materi pendidikan literasi finansial pada siswa kelas II terintegrasi pada pelajaran matematika, sedangkan pada siswa kelas V terintegrasi pada pelajaran IPS.

Sekolah juga menyediakan sarana literasi yang mendukung pelaksanaan pendidikan literasi finansial, meliputi perpustakaan sekolah dan sudut baca kelas. Hal ini sesuai buku panduan Gerakan Literasi Sekolah bahwa perpustakaan sekolah berfungsi sebagai pusat pengelolaan pengetahuan dan sumber belajar; perpustakaan dapat dikelola oleh tim perpustakaan yang terlatih dalam pengelolaan bahan literasi; sebaiknya perpustakaan dilengkapi sistem dan aplikasi untuk mencatat pengunjung, dan aktivitas membaca, dan sarana literasi lain (Faizah, dkk, 2016). Ketersediaan variatif bahan bacaan termasuk dalam sumber pendukung dalam pelaksanaan pendidikan literasi finansial. Ketersediaan bahan bacaan finansial yang bervariatif dapat menarik dan memotivasi siswa untuk membaca buku yang berhubungan dengan pendidikan finansial. Hal tersebut sesuai dengan penelitian yang dilakukan oleh Guthrie \& Humenick (2004) bahwa ketersedian berbagai pilihan bahan bacaan dalam kegiatan membaca dapat meningkatkan motivasi siswa untuk membaca.

\section{Metode dan Media Pembelajaran Pelaksanaan Pendidikan Literasi Finansial di Sekolah Dasar}

Salah satu prinsip-prinsip pendidikan literasi finansial menjelaskan bahwa guru harus memberikan pembelajaran yang efektif. Pembelajaran efektif dalam prosesnya terjadi jika siswa dapat terlibat aktif dalam melaksanakan tahapan prosedur pembelajaran dan dapat tercapainya tujuan pembelajaran. Pembelajaran efektif ini akan berhasil, jika guru dapat menggunakan berbagai metode yang bervariasi. Menurut Moesly (2016) guru dapat mengajarkan konsep literasi finansial secara efektif dengan menggunakan berbagai macam metode pembelajaran yang dapat membantu siswa dalam memahami materi dan mencapai tujuan pembelajaran yang diharapkan. Penjelasan tersebut sangat mendukung kegiatan yang ada di lapangan yaitu guru sudah menggunakan berbagai metode sesuai dengan jenjang kelasnya dalam mengajarkan pendidikan literasi finansial. Menurut Roof (2004) guru dapat menggunakan berbagai macam metode pembelajaran yang disesuaikan dengan usia siswa agar dapat membantu meningkatkan pemahaman terkait konsep finansial. Guru juga menggunakan metode dalam mengajarkan pendidikan literasi finansial. Metode tersebut yaitu metode diskusi, karyawisata dengan datang ke pasar untuk mewawancarai penjual, dan metode pemecahan masalah dalam menentukan kesederhanaan dengan membandingkan harga. Siswa sangat aktif dan antusias dalam mengikuti pembelajaran.

Materi yang berhubungan dengan pendidikan literasi finansial di sekolah dasar terkadang memiliki sifat yang abstrak. Konsep yang bersifat abstrak ini harus dipahami dan tersampaikan kepada siswa dengan baik serta dapat mengaplikasikan materi yang diajarkan dalam kehidupan sehari-hari. Konsep yang bersifat abstrak ini akan mudah dipahami siswa jika materi bersifat konkret (nyata). Materi dapat bersifat konkret, jika guru dapat menggunakan media pembelajaran (Asnawir, 2002). Menurut Daryanto (2010) media pembelajaran adalah sarana perantara dalam proses pembelajaran. Sarana perantara disini 
dapat berupa alat dan bahan pendukung kegiatan pembelajaran. Berdasarkan penjelasan di atas, fakta di lapangan menunjukkan bahwa guru sekolah dasar sudah menggunakan media pembelajaran dalam membantu pemahaman konsep finansial siswa. Menurut Nomleni (2018) penggunaan media dalam pembelajaran dapat meningkatkan pemahaman konsep pada siswa. Guru menggunakan media video untuk menampilkan jenis-jenis ekonomi yang ada di masyarakat. Penggunaan media pembelajaran dapat membantu antusias siswa dalam membangkitkan keingintahuan siswa dengan materi yang akan diajarkan.

\section{SIMPULAN}

Berdasarkan hasil data penelitian diatas, dapat diperoleh simpulan sebagai berikut. Pelaksanaan pendidikan literasi finansial terintegrasi dalam mata pelajaran lain. Di sekolah dasar setiap jenjang kelas II-V sudah tersedia kompetensi dasar yang berkaitan dengan pendidikan literasi finansial. Kompetensi dasar ini dapat ditemukan pada mata pelajaran matematika dan ilmu pengetahuan sosial. Pendidikan literasi finansial harus menjadikan pembelajaran yang berpusat pada siswa. Guru dapat dikatakan telah mengajarkan pendidikan literasi finansial, jika dalam pembelajarannya menggunakan berbagai metode dan media pembelajaran. Metode dan media pembelajaran akan memberikan kemudahan kepada siswa dalam memahami materi finansial yang akan bersifat konkret.

Berdasarkan kesimpulan dari paparan data yang didapatkan selama melakukaan penelitian, penulis memberikan beberapa saran yang dapat menjadikan pendidikan literasi finansial dilaksanakan secara optimal. Pertama, pihak sekolah diharapkan dapat selalu meningkatkan program kegiatan yang berhubungan pendidikan literasi finansial di sekolah dasar. Kedua, guru sebagai peranan utama dalam pelaksanaan pendidikan literasi finasial basis kelas disarankan dapat selalu menggunakan berbagai metode, model dan media dalam pembelajaran khusunya konsep finansial. Ketiga, peneliti dapat menggunakan penelitian ini sebagai bahan referensi untuk peneliti tentang pendidikan literasi finansial di sekolah dasar. Peneliti lainnya juga disarankan dapat meneliti tentang dampak siswa dalam pendidikan literasi finansial di sekolah dasar terhadap sikap jiwa kewirausahaan.

\section{DAFTAR RUJUKAN}

Asnawir., \& Usman. (2002). Media Pembelajaran. Jakarta: Ciputra Pers.

Batty, M., Collins, J. M., \& Odders-White, E. (2015). Experimental Evidence on the Effects of Financial Education on Elementary School Students’ Knowledge, Behavior, and Attitudes. Journal of Consumer Affairs, 49(1), 69-96. https://doi.org/10.1111/joca.12058

Cresswell, J. W. (2018). Penelitian Kualitatif \& Desain Riset (Memilih di antara Lima Pendekatan. Diterjemahkan oleh Ahmad Lintang Lazuardi. Yogyakarta: Pustaka Pelajar.

Daryanto. (2012). Media Pembelajaran. Bandung: PT Sarana Tutorial Nurani Sejahtera.

Delgadillo, L. (2014). Financial Clarity: Education, Literacy, Capability, Conseling, Planning, and Coaching. Family and Consumer Sciences Research Journal, 43(1), 18-19. DOI: https://doi.org/10.1111/fcsr.12078

Dikdasmen, D. (2017). Materi Pendukung Literasi Finansial. Jakarta: Kementerian Pendidikan dan Kebudayaan Republik Indonesia.

Elonge, M. (2013). An Evaluation of Financial Literacy in Elementary Schools towards Financial Education Enhancement: A Case Study of Baltimore Public Schools. Literacy Information and Computer Educational Journal, 4(4), $1283-1291$.

Guthrie, J. T., \& Humenick, N. M. (2004). Motivating Students to Read: Evidence for Classroom Practices that Increase Reading Motivaton and Achievement. Baltimore, MD: Paul H. Brookes Publishing Co.

Jackson. (2013). Cha-Ching Money Smart Kids Fact Sheet. North America: Discovery Education.

Johnson, E., \& Sherraden, M. (2006). From Financial Literacy to Financial Capability Amongst Youth. CSD Working Paper 06-11, 34(3).

Lindawati, M. L., \& Suyanto. (2015). Peran Koperasi dalam Meningkatkan Sikap Kewirausahaan Siswa SMK Negeri 1 Wonogiri. Harmoni Sosial: Jurnal Pendidikan IPS, 2(2), 170-180.

Mosley. (2006). Building an Effective Financial Literacy Program. New York: Wisconsin Department of Public Instruction.(https://dpi.wi.gov/sites/default/files/imce/cte/pdf/pflchap1.pdf.

Nomleni, F., \& Manu, T. (2018). Pengembangan Media Audio Visual dan Alat Peraga dalam Meningkatkan Pemahaman Konsep dan Pemecahan Masalah. Jurnal Pendidikan dan Kebudayaan, 8(3), 219-230 DOI: https://doi.org/10.24246/j.js.2018.v8.i3

Osalusi \& Oluwaghohunmi. 2014. Perspectives on Literacy as a Tool for Sustainable Social Relationship. International Journal of Education \& Literacy Studies, 2(1), 40-45.

Otto, A., Schots, P., Westerman, J., \& Webly, P. (2005). Children's Use of Saving Strategi: An Experimental Approach. Journal of Economic Psychology, 27(1), 57-72. DOI: 10.1016/j.joep.2005.06.013Owen.

Permata, B., Wahyono, H., \& Wardoyo, C. (2017). Bahan Ajar Berbasis Cerita untuk Menanamkan Literasi Ekonomi pada Siswa Sekolah Dasar. Jurnal Pendidikan: Teori, Penelitian, dan Pengembangan, 2(3), 356-362.

Roof, V., \& Chiroro, P., Coppenhagen, C., \& Smith, I., \& Heerden, C., \& Abdoola, R., \& Robertson \& Beukes, C. (2002). Money Adventure: Introducing Economic Concepts to Preschool Childern in the South African Context. Journal of Economic Psychology, 26(2), 243-254. 